Original article

\title{
Increasing antioxidant activity of soursop (Annona muricata L.) and noni (Morinda citrifolia L.) leaves fermented by Lactobacillus plantarum BP102
}

\author{
Dayu Nirwana Putri ${ }^{1}$, Sri Widyarti ${ }^{2}$, Yoga Dwi Jatmiko ${ }^{2 *}$ \\ ${ }^{1}$ Master Study of Biology, Department of Biology, Faculty of Mathematics and Natural Sciences, Universitas Brawijaya, Malang, Indonesia 65145 \\ ${ }^{2}$ Department of Biology, Faculty of Mathematics and Natural Sciences, Universitas Brawijaya, Malang, Indonesia 65145
}

Abstract

Free radicals are constantly produced by either cell metabolism or from external sources. At high concentration, they induced a tissue damage called oxidative stress. Soursop leaf (Annona muricata L.) and noni leaf (Morinda citrifolia L.) are medicinal plants with potency as antioxidants. This study aimed to evaluate the capacity of Lactobacillus plantarum BP102 in elevating the antioxidant activity of soursop and noni leaves. Dried-powder and methanol extract of soursop and noni leaves were diluted with sterile distilled water $3 \mathrm{~g} / 30 \mathrm{~mL}$ and $0.3 \mathrm{~g} / 30 \mathrm{~mL}$, respectively, inoculated with $1 \%$ (v/v) of L. plantarum BP102 inoculum. The antioxidant activity was carried out using the 2.2-diphenyl-1-picrylhydrazyl (DPPH) method. The antioxidant activity increased in dried-powder and methanol extract of soursop and noni leaves with different activity levels after being fermented using $L$. plantarum $\mathrm{BP} 102$ based on $\mathrm{IC}_{50}$. The increasing antioxidant activity in dried-powder of soursop leaves $\mathrm{IC}_{50} 6.41 \pm 0.06$ to $0.034 \pm 0.01 \mathrm{mg} / \mathrm{mL}(99.5 \%)$ was higher than of the methanol extract $\mathrm{IC}_{50} 2.78 \pm 0.00$ to $0.11 \pm 0.01 \mathrm{mg} / \mathrm{mL}(96 \%)$. Unfortunately, the effect of fermentation towards noni leaves could only be observed in the form of methanol extract $\mathrm{IC}_{50} 12.8 \pm 0.01$ to $0.33 \pm 0.02 \mathrm{mg} / \mathrm{mL}$ (increased by $97.4 \%$ ), the dried-powder of noni leaves was suspended and produced a dark color. The probiotic L. plantarum BP102 was used as a fermented agent in increasing the bioactive compounds especially related to antioxidant activity.

Keywords: antioxidant, fermented plant extract, Lactobacillus plantarum, noni leaf, soursop leaf

Received: October 18, 2021 Revised: December 24, 2021 Accepted: January 4, 2022

\section{Introduction}

Free radicals are molecules or atoms that have unstable and having one unpaired electron in its outermost orbit (Sukweenadhi et al., 2020). The increase of free radicals should be balanced by antioxidants to prevent oxidative stress. Oxidative stress is a significant factor causing inflammation, such as asthma, arthritis, stroke, heart disease, hypertension, Parkinson's, preeclampsia, atherosclerosis, Alzheimer's, and many other disorders (Chiavaroli et al., 2011, Mahdi-Pour et al., 2012). Antioxidants are defined as substances that delay or inhibit oxidative damage.

It is already known that probiotics have health benefits to the gut microbiota, modulating the immune system (preventing allergies, enhancing the immune system), and producing antimicrobial compounds (Manhar et al., 2016, Mulaw et al., 2019). In recent years, probiotic products have become popular all over the world (Guan et al., 2020). Lactic acid bacteria as probiotic also played an important role in the fermentation of plant extracts to increase the bioactive compounds exerting antioxidant activity. Lactobacillus plantarum is a member of lactic acid bacteria that has potential as a probiotic. Several studies reported that Ginseng marc fermented with $L$. plantarum could increase antioxidant activity and the content of active compounds of ginseng marc in the form

\section{* Corresponding Author:}

Yoga Dwi Jatmiko

Department of Biology, Faculty of Mathematics and Natural

Sciences, Universitas Brawijaya, Veteran Street, Malang,

Indonesia 65145

Phone: +62 857-3740-1099 Fax: +62341 554403

E-mail: jatmiko_yd@ub.ac.id of phenolics and flavonoids by 32.4 and $23.3 \%$, respectively (Eom et al., 2017). The effect of papaya juice fermented with $L$. acidophilus and $L$. plantarum experienced similar changes in $\mathrm{pH}$ and reduction in sugar content during the $48 \mathrm{~h}$ of fermentation period. However, $L$. plantarum resulted in a better antioxidant activity than of L. acidophilus after $48 \mathrm{~h}$ of fermentation (Chen et al., 2018). Olives fermented with $L$. plantarum also can increase antioxidant activity by $24 \%$ (Kachouri et al., 2015).

Natural antioxidants are generally found in medicinal plants, such as soursop leaf (Annona muricata L.) and noni leaf (Morinda citrifolia L.). Noni leaf and soursop leaf have been a popular herbal medicine and have antioxidant activity (Serafini et al., 2011, Sari, 2015). Several studies reported that the ethanolic extract of soursop leaves contains steroids, alkaloids, flavonoids, and saponins (Hasmila et al., 2019). Noni leaves extract contains active compounds, namely lignans, organic acids, alkaloids, flavonoids, triterpenoids, sterols, iridoids, chlorophyll derivatives, coumarin derivatives, and are potential sources of antioxidants and phenols (Kovendana et al,. 2014, Krishnaiah et al., 2015).

The preliminary test results of LC-MS analysis of dried-powder of soursop leaves identified 166 active compounds, while the methanol extract of soursop leaves identified 191 active compounds. On the other hand, the results of LC-MS analysis of dried-powder of noni leaves identified 108 active compounds. Meanwhile, methanol extract of noni leaves identified 120 active compounds. Therefore, it is essential to compare the antioxidant activity of dried-powder and methanol extract of soursop and noni leaves fermented by L. plantarum 
BP102, thus a promising alternative to boosting antioxidants. L. plantarum BP102 isolates from garlic bulb was chosen because resistance to low $\mathrm{pH}$, bile salt, has the best probiotic characteristics, and has the potential as a starter culture for fermenting medicinal plants (Wardhani, 2019). This study aimed to determine the difference in antioxidant activity of dried-powder and methanol extract of soursop and noni leaves using the DPPH method (2.2-diphenyl-1-picrylhydrazyl) based on the $\mathrm{IC}_{50}$ value before and after fermentation by L. plantarum BP102.

\section{Methods}

\section{Materials and bacterial culture}

Soursop and noni leaves were obtained from the UPT Laboratorium Herbal Materia Medica, Batu, East Java. The mature soursop and noni leaves were selected from the middle between the base and the tip of the twig. $L$. plantarum BP102 is endophytic LAB isolated from garlic bulb were obtained from the collection of the Laboratory of Microbiology, Faculty of Mathematics and Natural Sciences, Universitas Brawijaya, Malang. The probiotic properties were cultured in MRS media (Merck, Darmstadt, Germany). One loop-full of L. plantarum BP102 and was transferred to $9 \mathrm{~mL}$ of sterile MRS Broth and incubated at $37^{\circ} \mathrm{C}$ for $24 \mathrm{~h}$ to achieve a cell density of $10^{8}$ cell $/ \mathrm{mL}$ calculated using Hemocytometer as starter culture for fermentation of plant extract (Wen et al., 2013). The solvents for extraction and radical scavenging activity assays used methanol. The 2,2-diphenyl-1picrylhydrazyl radical (DPPH) was purchased from Sigma-Aldrich Chemie (Steinheim, Germany).

\section{Fermentation of plant and extract}

The soursop and noni leaves were air dried without sunlight at room temperature $\left(27-32^{\circ} \mathrm{C}\right)$ for one week, then baked in the oven at $60^{\circ} \mathrm{C}$ until dry and ground using a blender to form a dried-powder size 90 mesh. The processing methods of soursop and noni leaves were conducted using two treatments. The first treatment was a dried-powder form (without extraction). The second treatment was extract methanol of soursop and noni leaves was prepared by maceration using methanol $(1: 10$, $\mathrm{w} / \mathrm{v})$, at room temperature for $72 \mathrm{~h}$ and stirred every $6 \mathrm{~h}$. The extract was then filtered using Whatman Filter paper No. 1 and evaporated in a rotary evaporator at $40^{\circ} \mathrm{C}$, pressure of $175 \mathrm{bar}$, for approximately $3 \mathrm{~h}$. The extract was weighed to calculate the yield and wrapped in black plastic was stored at $4^{\circ} \mathrm{C}$ until used (Ahmed et al., 2015, Almoulah et al., 2017).

The dried-powder $(3 \mathrm{~g})$ of soursop and noni leaves were dissolved in $30 \mathrm{~mL}$ of sterile distilled water. The methanol extract $(0.3 \mathrm{~g})$ of soursop and noni leaves added $0.5 \%$ of tween 20 to increase its solubility and dissolved in $30 \mathrm{~mL}$ of sterile distilled water. The driedpowder and methanol extract of soursop and noni leaves are fermented separately. Starter culture of L. plantarum BP102 1\% (v/v) was inoculated into the suspension of dried-powder and methanol extract, and then incubated at $37^{\circ} \mathrm{C}$ for $24 \mathrm{~h}$ under stirring conditions. Finally, the fermented products were centrifuged at $4.000 \mathrm{rpm}$ for 20 min at $4^{\circ} \mathrm{C}$ to obtain a cell-free supernatant (CFS) (Eom et al., 2017).

\section{DPPH antioxidant activity analysis}

The dried-powder $(0.25 \mathrm{~g})$ and methanol extract $(0.1$ g) samples either before or after fermentation were dissolved in $10 \mathrm{~mL}$ of methanol. The samples were made in various series concentrations namely $(25,50,75,100$, and $125 \mathrm{mg} / \mathrm{mL}$ ). Each concentration was added with $140 \mu \mathrm{L}$ of DPPH $\left(0.6 \times 10^{-6} \mathrm{~mol} / \mathrm{L}\right)$. After being incubated for $30 \mathrm{~min}$ at room temperature in the dark condition, samples absorbance were measured at a wavelength of $516 \mathrm{~nm}$ using UV-vis spectrophotometer (Shimadzu, Japan) (Almoulah et al., 2017, Hidayat et al., 2017). Methanol was use as blank, while the control was DPPH reagent and methanol (without samples). Ascorbic acid $(200 \mu \mathrm{L})$ was also used as the comparison control. The experiment was conducted in triplicates. The percentage of inhibitory activity of antioxidant was calculated by the following equation (Elfahri et al., 2016, Hrichi et al., 2020):

$$
\% \text { Inhibitory activity of antioxidant }=\frac{\text { Abs control }- \text { Abs sample }}{A b s \text { control }} \times 100 \%
$$

The $\mathrm{IC}_{50}$ value was determined using the regression equation, sample concentration on $\mathrm{X}$-axis and percentage of inhibitory activity of antioxidants on Y-axis. The smaller the $\mathrm{IC}_{50}$ (Inhibitory Concentration) value, the greater the antioxidant activity. A compound was categorized as a very strong antioxidant if the $\mathrm{IC}_{50}$ value was less than $0.05 \mathrm{mg} / \mathrm{mL}$, a strong antioxidant has IC50 value of $0.05-0.1 \mathrm{mg} / \mathrm{mL}$, a medium antioxidant has $\mathrm{IC}_{50}$ of $0.1-1.5 \mathrm{mg} / \mathrm{mL}$, and a weak antioxidant has $\mathrm{IC}_{50}$ values of 1.51-0.2 mg/mL (Molyneux, 2004).

\section{Results}

The yield of soursop leaf extract was $20.58 \%$, while the noni leaf extract was $9.93 \%$. The antioxidant test results showed an effect in antioxidant activity after fermentation with L. plantarum BP102 were shown in Table 1. The antioxidant activity of dried-powder and methanol extract of soursop leaves increased after fermentation with $\mathrm{IC}_{50}$ value of $(0.034 \mathrm{mg} / \mathrm{mL}$ and 0.11 $\mathrm{mg} / \mathrm{mL}$ ), respectively, if it was compared to before fermentation $(6.41 \mathrm{mg} / \mathrm{mL}$ and $2.78 \mathrm{mg} / \mathrm{mL}$, respectively). The dried-powder noni leaves exhibited an $\mathrm{IC}_{50}$ value of $58.05 \mathrm{mg} / \mathrm{mL}$. Unfortunately, fermented dried-powder of noni leaves failed to get $\mathrm{IC}_{50}$ value because the sample was suspended and produced a dark color. The $\mathrm{IC}_{50}$ value of methanol extract of noni leaves after being fermented was increased by $97.4 \%$

The highest antioxidant activity in the samples before being fermented based on the $\mathrm{IC}_{50}$ value was soursop leaf extract and noni leaf extract, namely $2.78 \mathrm{mg} / \mathrm{mL}$ and $12.8 \mathrm{mg} / \mathrm{mL}$, respectively. The extraction process has succeeded in acquiring antioxidant compounds thoroughly. The antioxidant category in the non-fermented samples was classified as very weak $(>0.2 \mathrm{mg} / \mathrm{mL})$, possibly due to the low antioxidant compounds in the samples. Meanwhile, in the fermented samples, the antioxidant category of soursop leaf powder was classified as very 
strong $(<0.05 \mathrm{mg} / \mathrm{mL})$, while soursop leaf extract was

categorized as medium $(0.1-1.5 \mathrm{mg} / \mathrm{mL})$.

Table 1. The IC 50 value of soursop and noni leaves before and after fermentation.

\begin{tabular}{|c|c|c|c|c|c|c|}
\hline \multirow[b]{2}{*}{ Samples } & & \multicolumn{2}{|c|}{ Before Fermentation } & \multicolumn{2}{|c|}{ After Fermentation } & \multirow{2}{*}{$\begin{array}{l}\text { Increasing } \\
\text { Antioxidant Activity } \\
(\%)\end{array}$} \\
\hline & & $\mathrm{IC}_{50}(\mathrm{mg} / \mathrm{mL})$ & $\begin{array}{l}\text { Antioxidant } \\
\text { Level }\end{array}$ & $\mathrm{IC}_{50}(\mathrm{mg} / \mathrm{mL})$ & $\begin{array}{l}\text { Antioxidant } \\
\text { Level }\end{array}$ & \\
\hline \multirow{2}{*}{$\begin{array}{l}\text { Soursop } \\
\text { leaves }\end{array}$} & dried-powder & $6.41 \pm 0.06$ & very weak & $0.034 \pm 0.01$ & very strong & 99.5 \\
\hline & $\begin{array}{l}\text { methanol } \\
\text { extract }\end{array}$ & $2.78 \pm 0.00$ & very weak & $0.11 \pm 0.01$ & medium & 96 \\
\hline \multirow{2}{*}{$\begin{array}{l}\text { Noni } \\
\text { leaves }\end{array}$} & dried-powder & $58.05 \pm 0.67$ & very weak & n.a* & n. $a^{*}$ & n.a* \\
\hline & $\begin{array}{l}\text { methanol } \\
\text { extract }\end{array}$ & $12.8 \pm 0.01$ & very weak & $0.33 \pm 0.02$ & medium & 97.4 \\
\hline Control & Ascorbic acid & & $0.002 \pm 0.00$ & & very strong & - \\
\hline
\end{tabular}

n.a*: sample is not sufficient for analysis

\section{Discussion}

Antioxidants are essential substances because they can protect from the oxidative stress due to free radicals (Mahdi-Pour et al., 2012). The determination of the value of antioxidant activity in this study using the DPPH method (2.2-diphenyl-1-picrylhydrazyl) was fast, easy, and required a small number of samples to evaluate the antioxidant activity. The DPPH assay has been widely used to examine the ability of compounds that act as antioxidants electron donors (Zhang et al., 2017).

The principle of this method is the measurement of DPPH radical capture by compounds that have antioxidant activity using UV-Vis spectrophotometry so that the value of free radical scavenging activity is known, which is expressed by the $\mathrm{IC}_{50}$ value. The $\mathrm{IC}_{50}$ value is defined as the concentration of the sample that reduces free radicals by $50 \%$. Thus, the smaller the $\mathrm{IC}_{50}$ value, the higher the free radical scavenging activity (Batubara et al., 2020).

The use of methanol as the solvent for extraction because flavonoids compounds were soluble in polar solvents. It was carried out to obtain a high antioxidant content and prevented damage to active compounds due to heating (Ukwubile, 2013, Gavamukulya et al., 2014, Sivasamugham et al., 2021). Another study stated that Syzygium polyanthum leaves extracted by the maceration method had a total phenolic content of $338.62 \pm 21.3 \mathrm{mgGAE} / \mathrm{g}$ and antioxidants with $\mathrm{IC}_{50}$ of $17.53 \pm 0.11 \mathrm{~g} / \mathrm{mL}$ higher than using the soxhlet and infusion methods (Luliana et al., 2019). According to Almoulah et al. (2017) the extraction process is a mass transfer process from the solid components in the sample into the organic solvent used. Organic solvents will penetrate the cell wall and then enter the plant cells' cavity containing bioactive substances. Then the substances will be dissolved in an organic solvent outside the cell to further diffuse into the solvent, thereby attracting all the active substances and chemical components in the sample.

Fermentation is the process of decomposition of organic compounds to produce energy and the conversion of substrates into new products by microbes. Thus changing the appearance, taste, function, nutritional composition, color, and texture.
The fermentation process produces a beneficial effect, namely the production of metabolites and other complex compounds beneficial to health (Kuria et al., 2021). When the acidity of the samples increased, this indicated that L. plantarum grew and utilized sugar, carbohydrates, and fiber from soursop and noni leaves to produce organic acids, especially lactic acid, and other by-products. Of most acidity that can be titrated, lactic acid is the primary organic acid produced by the genus Lactobacillus (Di Cagno et al., 2013, Nguyen et al., 2019). The effect of fermentation on increasing antioxidant activity was caused by an increase in the number of phenolic compounds and flavonoids during fermentation, resulting from microbial hydrolysis reactions. In addition, fermentation induces structural damage to plant cell walls, which leads to the synthesis of various antioxidant compounds. The antioxidant compounds can act as free radical terminators, metal chelators, singlet oxygen quenchers, or hydrogen donors for radicals. In addition, the production of proteases, amylase, and some other enzymes can be affected by fermentation which may have metal ion chelation activity (Hur et al., 2014, Maryati et al., 2020).

Antioxidant activity was influenced by the method, solvent and the extraction time factor. The extraction time that was too short will cause the bioactive components extracted from the material to be not optimal. On the other hand, if the extraction time is extended, the solvent will be saturated so that the results of the antioxidant activity were low (Yuliantari, 2017). This research is relevant to Xiao et al. (2015) study, which stated that fermentation on soy whey using L. plantarum B1-6 increases the antioxidant activity of $92,85 \pm 0,24 \%$. Previous research stated phytochemical composition and antioxidant activity Moringa oleifera leaves powder fermented by Lactobacillus plantarum (DSM 2601) and Weissella cibaria (27A). The fermentation by Lactobacillus plantarum (DMS 2601) showed there was an effect of the fermentation time on the content of phenolic compounds (Nirina et al., 2017). However, no study reported the antioxidant analysis on leaves extract fermented by L. plantarum. This study concludes that 
fermentation using L. plantarum BP102 can increase antioxidant activity as indicated by very strong antioxidant levels in dried-powder of soursop leaves. Meanwhile, the fermented soursop and noni leaves extracts were categorized as medium antioxidant activity level. The changes of the bioactive compounds related to antioxidant activity after being fermented is warrant to be investigated further.

\section{Acknowledgement}

The author would like to thank Ms. Nanik Dwirahayu for her laboratory technical assistance in the Laboratory of Microbiology, Faculty of Mathematics and Natural Sciences, Universitas Brawijaya, Malang.

\section{References}

Ahmed D., Khan MM., and Saeed R. 2015. Comparative analysis of phenolics, flavonoids, and antioxidant and antibacterial potential of methanolic, hexanic, and aqueous extracts from Adiantum caudatum leaves. Antioxidant 4: 394-409.

Almoulah NF., Voynikov Y., Gevrenova R., Schohn H., Tzanova T., Yagi S., Thomas J., Mignard B., Ahmed AAA., El Siddig MA., Spina R., and Laurain-Mattar R. 2017. Antibacterial, antiproliferative and antioxidant activity of leaf extracts of selected Solanaceae species. South African Journal of Botany 112: 368-374.

Batubara R., Surjanto TI., Hanum A., Handika, and Affandi O. 2020. The screening of phytochemical and antioxidant activity of agarwood leaves (Aquilaria malaccensis) from two sites in North Sumatra, Indonesia. BIODIVERSITAS 21: 15881596.

Chen R., Chen W., Chen H., Zhang G., and Chen W. 2018. Comparative evaluation of the antioxidant capacities, organic acids, and volatiles of papaya juices fermented by Lactobacillus acidophilus and Lactobacillus plantarum. Journal of Food Quality 4: 1-12.

Chiavaroli V., Giannini C., De Marco S., Chiarelli F., and Mohn A. Unbalanced oxidant-antioxidant status and its effects in pediatric diseases. Redox Rep 16: 101-107.

Di Cagno R., Coda R., De Angelis M., Gobbetti M.. 2013. Exploitation of vegetables and fruits through lactic acid fermentation. Food Microbiol 33: 1-10.

Elfahri KR., Vasiljevic T., Yeager T., and Donkor ON. 2016. Anticolon cancer and antioxidant activities of bovine skim milk fermented by selected Lactobacillus helveticus strains. Journal of Dairy Science 99: 31-40.

Eom SJ., Hwang JE., Jung J., Jee HS., Kim KT., and Paik HD. 2017. Antioxidative and antibacterial activities on Staphylococcus aureus and Escherichia coli O157:H4 in milk with added ginseng marc extract fermented by Lactobacillus plantarum KCCM 11613P. Journal of Dairy Science 100: 7788-7792.

Gavamukulya Y., Abou-Elella F., Wamunyokoli F., and El-Shemy HA. 2014. Phytochemical screening, anti-oxidant activity and in vitro anticancer potential of ethanolic and water leaves extracts of Annona muricata (Graviola). Asian Pac J Trop Med 7: S355-S363.

Guan Q., Xiong T., and Xie M. 2020. Influence of probiotic fermented fruit and vegetables on human health and the related industrial development trend. Journal of Engineering 7: 212-218.

Hasmila I., Natsi H., and Soekamto NH. 2019. Phytochemical analysis and antioxidant activity of soursop leaf extract (Annona muricata Linn.). IOP Conf. Series: Journal of Physics: Conference Series 1341: 032027.

Hidayat MA., Fitri A., and Kuswandi B. 2017. Scanometry as microplate reader for high through put method based on DPPH dry reagent for antioxidant assay. Journal of Chinese Pharmaceutical Association 7(3): 395-400.
Hrichi S., Chaabane-Banaoues R., Giuffrida D., Mangraviti D., El Majdoub YO., Rigano F., Mondello L., Babba H., Mighr Z., and Cacciola F. 2020. Effect of seasonal variation on the chemical composition and antioxidant and antifungal activities of Convolvulus althaeoides L. leaf extracts. Arabian Journal of Chemistry 13: 5651-5668.

Hur SJ., Lee SY., Kim Y., Choi I., and Kim G. 2014. Effect of fermentation on the antioxidant activity in plant-based foods. Journal of Food Chemistry 160: 346-356.

Kachouri F., Ksontini H., Kraiem M., Setti K., Mechmeche M., and Hamdi M. 2015. Involvement of antioxidant activity of Lactobacillus plantarum on functional properties of olive phenolic compounds. J Food Sci Technol 52(12):79247933.

Kovendana K., Shanthakumar SP., Praseeja C., Kumar PM., Murugan M., Kadarkarai, and Vincent S. 2014. Mosquitocidal properties of Morinda citrifolia L. (Noni) (family: Rubiaceae) leaf extract and Metarhizium anisopliae against malaria vector, Anopheles stephensi Liston. (Diptera: Culicidae). Asian Pacific Journal of Tropical Disease 4: S173-S180.

Krishnaiah D., Bono A., Sarbatly R., and Anisuzzaman SM. 2015. Antioxidant activity and total phenolic content of an isolated Morinda citrifolia L. methanolic extract from polyethersulphone (pes) membrane separator. Journal of King Saud University-Engineering Sciences 27: 63-67.

Kuria MW., Matofari JW., and Nduko JM. 2021. Physicochemical, antioxidant, and sensory properties of functional mango (Mangifera indica L.) leather fermented by lactic acid bacteria. Journal of Agriculture and Food Research. 6: 1-9.

Luliana S., Riza H., and Indriyani EN. 2019. The effect of extraction methods on total phenolic content and antioxidant activity of salam leaves (Syzygium polyanthum) using DPPH $(1,1$ Diphenyl-2-Picrylhidrazil). Journal Traditional Medicine 24: $72-76$

Mahdi-Pour B., Jothy SL., Latha LY., Chen Y., and Sasidharan S. 2012. Antioxidant activity of methanol extracts of different parts of Lantana camara. Asian Pac J Trop Biomed 2: 960965.

Manhar AK., Bashir Y., Saikia D., Nath D., Gupta K., Konwar BK., Kumar R., Namsa ND., and Mandal M. 2016. Cellulolytic potential of probiotic Bacillus subtilis AMS6 isolated from traditional fermented soybean (churpi): an in-vitro study with regards to the application as an animal feed additive. Journal of Microbiological Research 186-187: 62-70.

Maryati Y., Agustine S., Nina A., Puspa DNL., and Aspiyanto. 2020. Effect of fermentation on antioxidant activities and betacyanin content of functional beverages from dragon fruit and beetroot. Jurnal Bioteknologi \& Biosains Indonesia 7: $48-58$.

Mulaw G., Tessema TS., Muleta D., and Tesfaye A. 2019. In vitro evaluation of probiotic properties of lactic acid bacteria isolated from some traditionally fermented Ethiopian food products. International Journal of Microbiology 1-11.

Molyneux P. 2004. The use of the stable free radikal diphenylpicrylhydrazyl (DPPH) for estimating antioxidant activity. Journal Science of Technology 26: 211-219.

Nguyen BT., Bujna E., Fekete N., and Tran ATM. 2019. Probiotic beverage from pineapple juice fermented with Lactobacillus and Bifidobacterium strains. Front in Nutrition Journal 6: 17.

Nirina HA., Rasoarinanahary M., Porphyre V., Hiol A., Remize F., and Razanamparany L. 2017. Phytochemical composition and antioxidant activity of fermented Moringa oleifera leaf powder. European Journal of Nutrition \& Food Safety 7: 77 83.

Sari CY. 2015. Penggunaan buah mengkudu (Morinda citrifolia L.) untuk menurunkan tekanan darah tinggi. Jurnal Majoriti 5: 34-40.

Serafini MR., Santos RC., Guimara es AG., dos Santos JPA., Santos ADC., Alves IA., Gelain DP., Nogueira PCL., QuintansJúnior LJ., Bonjardim LR., and Arau'jo AA. 2011. Morinda citrifolia Linn leaf extract possesses antioxidant activities and reduces nociceptive behavior and leukocyte migration. Journal of Medicinal Food 14: 1159-1166.

Sivasamugham LA., Nimalan V., and Subramaniam G. 2021 Antibacterial effects of Musa sp. ethanolic leaf extracts 
against methicillin-resistant and susceptible Staphylococcus aureus. South African Journal of Chemical Engineering 35:107-110.

Sukweenadhi J., Yunita O., Setiawan F., Kartini, Siagian MT. Danduru AP., and Avanti C. 2020. Antioxidant activity screening of seven Indonesian herbal extract. BIODIVERSITAS 21: 2062-2067.

Ukwubile CA. 2013. Phytochemical screening and anti-ovarian cancer properties of Annona muricata Linn (Annonaceae) seed ethanol extract. Int J Pharm Front Res 2: 9-17.

Wardhani AW. 2019. Eksplorasi bakteri asam laktat endofit yang berpotensi sebagai probiotik dari tanaman obat [Skripsi]. Malang: Malang Brawijaya Univ.

Wen Y-L., Yan L-P., and Chen C-S. 2013. Effects of fermentation treatment on antioxidant and antimicrobial activities of four common chinese herbal medicinal residues by Aspergillus oryzae. Journal of Food and Drug Analysis 21: 219-226.

Xiao Y., Wang L., Xin R., Wei L., Xiaohong C., Mei J., and Mingsheng D. 2015. Enhancement of the antioxidant capacity of soy whey by fermentation with Lactobacillus plantarum B1-6. Journal of Functional Foods 12: 33-44.

Yuliantari NWA., Widarta IWR., and Permana IDGM. 2017. Pengaruh suhu dan waktu ekstraksi terhadap kandungan flavonoid dan aktivitas antioksidan daun sirsak (Annona muricata L.) menggunakan ultrasonik. Scientific Journal of Food Technology 4:35-42.

Zhang Z., Tao X., Shah NP., and Wei H. 2016. Antagonistics against pathogenic Bacillus cereus in milk fermentation by Lactobacillus plantarum ZDY2013 and its anti-adhesion effect on Caco-2 cells against pathogens. Journal of Dairy Sci 99: 2666-267 